\title{
PELATIHAN BASIC GUIDING BAGI PEMANDU WISATA LOKAL DALAM PENGEMBANGAN EKOWISATA AIR TERJUN GEROJOG SAMBEH TIBU NAGA DI DESA MANGGIS KABUPATEN KARANGASEM
}

\author{
N.L.R. Purnawan ${ }^{1}$, I D.P. Singarsa ${ }^{2}$, I K. Sardiana ${ }^{2}$
}

\begin{abstract}
Abstrak
Pelatihan Basic Guiding merupakan salah satu kegiatan yang dirancang pelaksana KKN PPM di Desa Manggis, Kecamatan Manggis Kabupaten Karangasem dalam upaya peningkatan kapasitas SDM masyarakat sebagai pengelola potensi desa. Hal ini berkaitan dengan upaya pengembangan Desa Manggis sebagai desa wisata dan pengembangan ekowisata Air Terjun Gerojog Sambeh Tibu Naga sebagai ikon kepariwisataan di desa tersebut. Metode yang ditempuh untuk mencapai tujuan tersebut adalah melalui pendidikan, pelatihan, simulasi Ipteks, dan pendampingan. Materi mencakup tugas dan fungsi pokok dan etika pemandu serta keterampilan berkomunikasi yang efektif. Selain peningkatan kapasitas pemandu wisata lokal, luaran lainnya yang dihasilkan melalui kegiatan KKN PPM ini adalah buku saku sebagai panduan dasar melakukan aktivitas sebagai pemandu lokal.
\end{abstract}

Kata Kunci : kuliah kerja nyata, pengembangan, ekowisata, air terjun Gerojog Sambeh Tibu Naga, pelatihan pemandu lokal

\begin{abstract}
Basic Guiding Training is one of the activities designed by KKN PPM Manggis, Manggis District, Karangasem Regency in an effort to increase the capacity of community human resources as managers of village potential. In relation to the development planning of Manggis Village as a tourism village and the development of ecotourism of the Gerojog Sambeh Tibu Naga Waterfall as an icon of tourism in the village. The methods conducted through education, training, science and technology simulation, and mentoring. The material includes basic tasks and functions and guiding ethics and effective communication skills. In addition to increasing the capacity of local tour guides, other outcomes generated through the KKN PPM activities are pocketbooks as a basic guidance for those involved in the activities of guiding in the Manggis Village .
\end{abstract}

Key words : community engagement), development, ecotourism, Gerojog Sambeh Tibu Naga Waterfall, basic guiding

\footnotetext{
${ }^{1}$ Staf Pengajar FISIP Universitas Udayana, ramaswati.purnawan@unud.ac.id

${ }^{2}$ Staf Pengajar Program Studi Agroekoteknologi,Fakultas Pertanian Universitas Udayana,
} 


\section{Pendahuluan}

Kecamatan Manggis terletak di wilayah Kabupaten Karangasem, dengan luas wilayah $69.83 \mathrm{~km}^{2}$ dan jumlah penduduk lebih dari 45 ribu jiwa.di tahun 2016 (BPS, 2017). Kecamatan Manggis terdiri dari 12 desa, salah satunya adalah Desa Manggis.

Luas wilayah Desa Manggisitu sendiri adalah $9.85 \mathrm{~km}^{2}$ dengan sebagian besar daerah merupakan perkebunan dan persawahan. Letak geografis Desa Manggis yang berdekatan dengan ibukota kabupaten dan dekat dengan akses pantai, serta telah memiliki fasilitas akomodasi berupa tersedia hotel dan homestay disekitar Kecamatan Manggis, mendorong pengembangan kepariwisataan di wilayah tersebut. Hal ini diperkuat dengan ditetapkannya Desa Manggis sebagai salah satu Desa Wisata di Kabupaten Karangasem.

Selain potensi di atas, Desa Manggis juga memiliki potensi alam yang belum dimanfaatkan secara optimal yakni potensi pengembangan ekowisata dengan memanfaatkan air terjun yang ada di Desa Manggis, salah satunya adalah Air Terjun "Gerojog Sambeh Tibu Naga". Lokasi air terjun ini yang terletak di hutan yang masih lestari didukung oleh udara pegunungan yang sejuk menjadikan tempat menarik minat wisatawan untuk kegiatan ekowisata. Namun demikian, potensi daya tarik air terjun Gerojog Sambeh Tibu Naga sebagai obyek ekowisata yang begitu besar ternyata belum dikelola secara memadai untuk meningkatkan pendapatan bagi masyarakat setempat.

Persoalan yang dihadapi dalam pengembangan potensi pariwisata air terjun Gerojog Sambeh Tibu Naga di Kecamatan Manggis diantaranya : potensi yang belum dikemas maksimal, kelompok masyarakat sadar wisata (Pokdarwis) belum berjalan produktif dalam mengelola dan mengembangkan potensi yang ada, ketrampilan dan kemampuan SDM yang perlu ditingkatkan terkait manajemen dan pelayanan.

Pelibatan masyarakat desa dalam pengembangan desa wisata dalam berbagai tahapan kegiatan baik dalam tahap perencanaan, implementasi, maupun evaluasi. Hal ini penting dalam rangka menjaga kelestarian lingkungan desa (Sardiana and Purnawan, 2015). Program pemberdayaan masyarakat khususnya dalam kompetensi pengelolaan daya tarik wisata sangat diperlukan bagi pemanfataan sumber daya kepariwisataan desa secara optimal.

\section{Metode Pelaksanaan}

Metode yang diterapkan dalam kegiatan KKN PPM ini meliputi pelatihan pengembangan ekowisata. Untuk mencapai tujuan tersebut dilakukan kegiatan pendidikan, pelatihan,. simulasi Ipteks, dan pendampingan. Kegiatan pelatihan dan pendampingan dilakukan selama bulan Agustus 2018. 


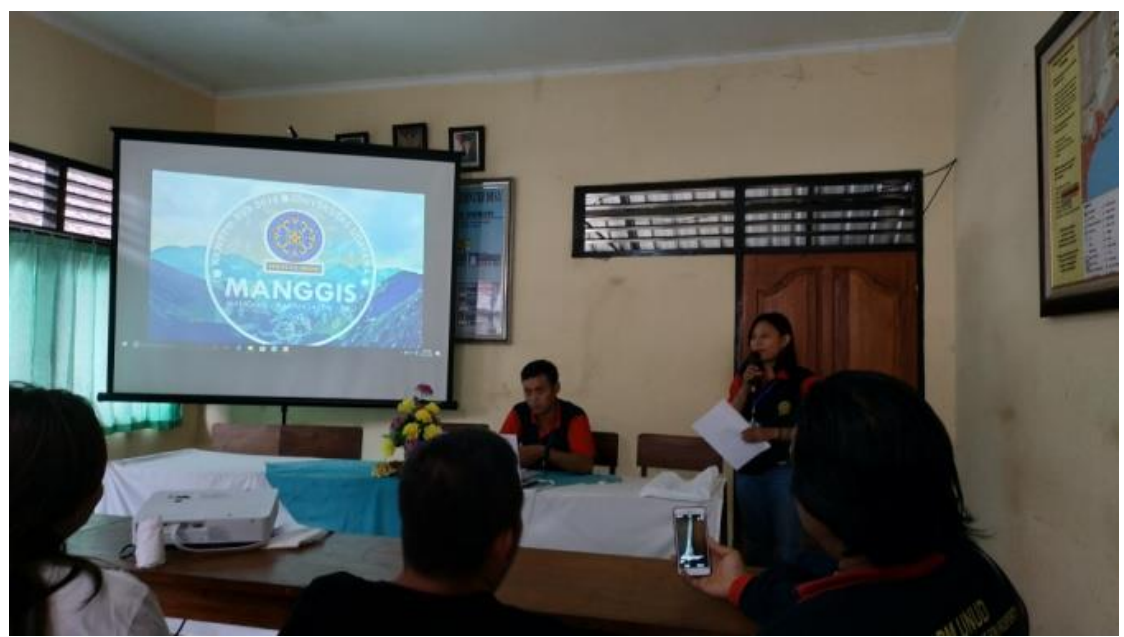

Gambar 1.1. Kegiatan Penyuluhan dan Pendampingan dalam KKN PPM Desa Manggis

\section{Hasil dan Pembahasan}

Materi yang diberikan terbagi menjadi dua bagian yakni, tugas dan fungsi pokok seorang pemandu wisata termasuk etika pemandu, serta pelatihan komunikasi yang efektif (effective communication) dalam menunjang aktivitas sebagai pemandu wisata.

Pelatihan diikuti oleh 15 orang anggota pemandu wisata lokal. Dari jumlah tersebut, 1 orang merupakan pemandu wisata perempuan, selebihnya merupakan pemandu wisata laki-laki. Hampir seluruh anggota tidak memiliki latar belakang pendidikan formal dalam bidang pariwisata, namun sebagian besar pernah bekerja berkaitan dengan sektor pariwisata di Kabupaten Karangasem.

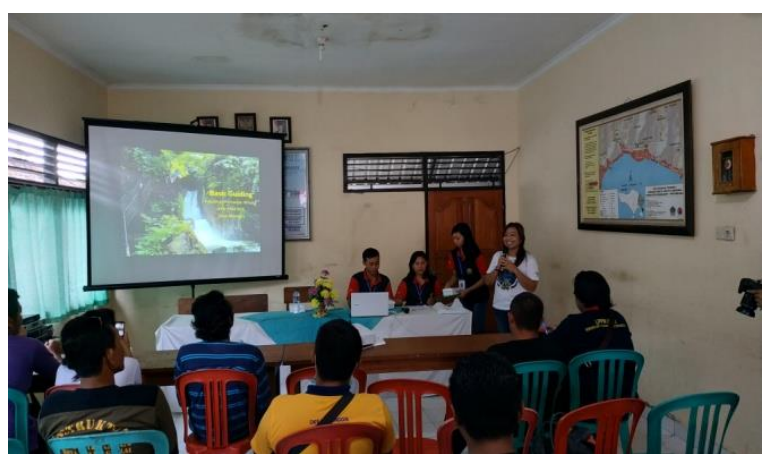

Gambar 1.2. Pelatihan dan pendampingan oleh pelaksana KKN PPM Desa Manggis

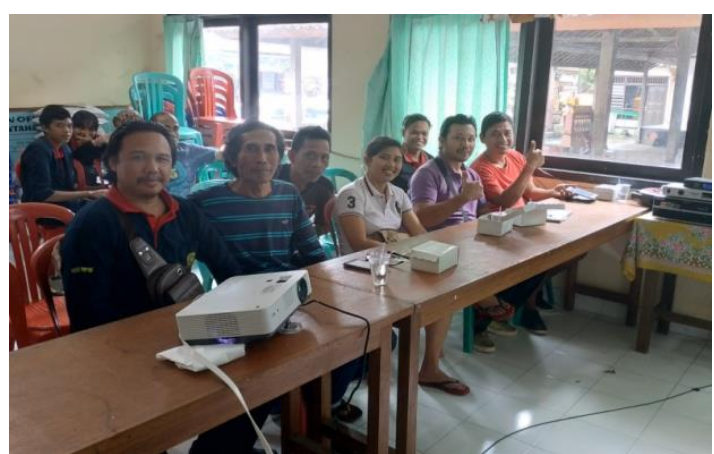

Gambar 1.3. Sebagian anggota pemandu wisata lokal Desa Manggis, Kabupaten Karangasem

Dalam pelatihan ditekankan bahwa tugas utama seorang pemandu wisata adalah menuntun (escorting) individu atau sekelompok orang yang berasal dari dalam negeri maupun luar negara asal pemandu untuk mengetahui suatu daya tarik wisata tertentu. Selain itu, pemandu wisata juga berperan sebagai introducer yang berfungsi untuk memperkenalkan dan membantu wisatawan untuk mengenal daerah yang dikunjungi. Dalam melaksanakan tugasnya seorang pemandu wisata dituntut untuk memiliki kualitas moral, intelektual dan profesionalisme.

Untuk menjadi seorang pemandu wisata yang baik, diperlukan kemampuan berkomunikasi sebagai dasar utama. Kemampuan berkomunikasi tidak saja mencakup kemampuan berbicara, namun juga keterampilan untuk mendengar dan berempati. 
Sebagai salah satu luaran dari kegiatan pelatihan dan pendampingan bagi pemandu wisata lokal, KKN PPM Desa Manggis, menerbitkan buku saku Basic Guiding yang dapat dimanfaatkan bagi para pemandu lokal untuk meningkatkan keterampilan memandu dan penguasaan bahasa asing.

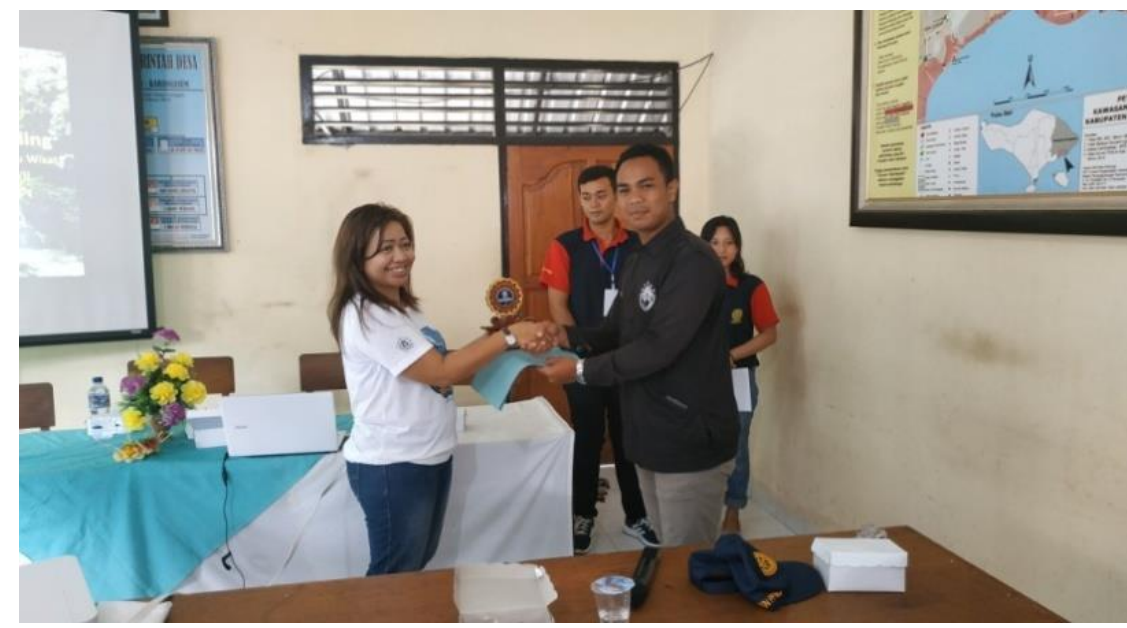

Gambar 1.4. Akhir pelaksanaan pelatihan dan pendampingan

\section{Kesimpulan dan Saran}

\section{Kesimpulan}

1. Pengembangan desa wisata melalui pengembangan paket ekowisata mendapat sambutan positif dari masyarakat Desa Manggis Kabupaten Karangasem

2. Pengembangan potensi desa merupakan alternative kepariwisataan Bali yang dapat dikembangkan untuk meningkatkan kesejahteraan hidup masyarakat lokal, sekaligus sebagai upaya pelestarian lingkungan menuju keberlanjutan.

\section{Saran}

1. Diperlukan pelatihan dan pendampingan lebih lanjut dan terintegrasi antara pemerintah Kabupaten Karangasem melalui OPD terkait, akademisi dan industri pariwisata agar masyarakat Desa Wisata dapat mengelola potensi tersebut secara mandiri dan dimanfaatkan untuk sebesar-besarnya peningkatan kesejahteraan masyarakat lokal.

\section{Ucapan Terima Kasih}

Ucapan terimakasih yang sebesar-besarnya kami sampaikan kepada berbagai pihak yang telah membantu pelaksanaan kegiatan KKN PPM ini, yakni DRPM Kemenristek Dikti atas bantuan dana kegiatan KKN PPM Tahun 2018.

Selain itu, kami juga mengucapkan terimakasih kepada Universitas Udayana melalui kegiatan KKN PPM; Pemda Kabupaten Karangasem, beserta aparat Desa, Pokdarwis dan masyarakat Desa Manggis; serta mahasiswa KKN Desa Manggis 2018, sehingga kegiatan KKN PPM ini dapat terlaksana dengan baik.

\section{Daftar Pustaka}


Badan Pusat Stratistik Kabupaten Karangasem, 2017. Kecamatan Manggis Dalam Angka 2017, Amlapura: Percetakan Teleng Indah

Kementerian Pariwisata dan Ekonomi Kreatif (2012) Pedoman Kelompok Sadar Wisata. Jakarta

McLeod, N (2006) 'Cultural Tourism : Aspects of Authenticity and Commodifiction' in Smith, MK and Robinson, M (eds) Cultural Tourism in a Changing World : Politics, Participation and (Re)presentation

Pitana, I Gde dan Surya Diarta, I Ketut (2009) Pengantar Ilmu Pariwisata. Yogyakarta : Penerbit ANDI

Sardiana, I.K. and N.L.R. Purnawan. 2016. Indegenous Community, Ecotourism and Sustainability: Experience from Tenganan dauh Tukad traditional village. Preceding of The $3^{\text {rd }}$ International Hospitality and Taourism Coference (IHTC, 2016) and $2^{\text {nd }}$ International Seminar on Taourism (ISOT 2016) : CRC Press. Pp 591-595

Sardiana, I.K. and N.L.R. Purnawan. 2015. Community-based Ecotourism in Tenganan Dauh Tukad: An Indigenous Conservation Perspective. Jurnal Kajian Bali (Journal of Bali Studies). Vol. 5 No. 2. Pp. 347-368

Vickers, Andrian (1989) Bali: A Paradise Created. Hongkong: Periplus www.kemenpar.go.id 